\title{
Reviews
}

Children and their Curriculum: The Perspectives of Primary and Elementary School Children

Edited by ANdrew Pollard, Dennis Thiessen and ANN Filer (Falmer Press, London, 1997), 206pp., \$24.95 (pbk), ISBN 0-7507-0594-9.

'Take pupil voices seriously!' could be an adequate subtitle of this book. The voices of pupils from both sides of the Atlantic and from different ethnic and socio-economic backgrounds are well represented. The urge to give these voices a legitimate place in curriculum thinking and curriculum development is the overarching theme that connects all chapters. However, readers who expect a book in which 'the innocent child' is pictured in a romantic way will be disappointed. Rather, a realistic portrayal is presented of how even young children deliberately shape their curriculum. In this process they sometimes consciously use rather sophisticated political strategies. The book stems from the Pupil Perspectives and the Curriculum symposium at the European Conference on Educational Research held at the University of Bath, UK, in September 1995.

Following an introductory chapter, selected papers written by authors from Canada, the UK, and the US are grouped around four themes. 'Pupils, Teachers and the Ownership of Curriculum Knowledge', consists of two chapters that share a concern about the negative implications of the National Curriculum in England for adaptive teaching. Bob Jeffrey and Peter Woods stand up for creative teaching and advocate the importance of engaging children in enacting the curriculum in the classroom. The central message of their chapter seems to be that teachers should definitely not become 'slaves to the National curriculum' (p. 32). Rod Parker-Rees' chapter is about two pupils who are apparently not gaining the full learning potential out of a science lesson. The author concludes from his research that the teacher is more focused on the planned curriculum than on adapting the curriculum to the children's needs. Rod Parker-Rees points to a vicious cycle: 'teachers have little time to talk with [pupils] about their learning so [pupils] have few opportunities to develop the skills that would enable them to tell teachers about their learning' (p. 46).

The second theme is 'Pupils' Lives and the Curriculum as Lived Experience'. In her chapter, Mary Maguire vividly describes the experiences of three Muslim girls at a Canadian elementary school. Taking their use of different languages as a focal point she gives a thoughtful account of how these girls manage to cross the borders of the different cultures and of how their family situation profoundly influences the way they take part in curriculum enactment processes. I think this chapter is particular appealing, because it gives a nonstereotypical portrayal of the three girls and because Mary Maguire has an open eye for the differences between the girls, partly due to their personal characteristics but also due to different influences of their home situation. In her chapter, Ann Filer starts with a critical analysis of the National 
Curriculum target of 'speaking and listening'. She argues that the underlying one-way performance model is not in line with the way children are engaged in more formal classroom conversations. She opts for an 'inter-organism' perspective as an alternative way of viewing language. Ann Filer illustrates her theoretical view with an in-depth analysis of the way primary pupils are engaged in the so-called 'news session'. In the classroom she studied, children are invited to share daily life experiences as a means to develop their communicative skills. The chapter depicts children having a sophisticated set of criteria to decide whether or not they will actively participate in news sessions and what kind of stories they will tell. One of the most important criteria is 'not being a bore'. Some of the children in the class consider this aspect so important that they deliberately tell a 'deviant comedy' (a story disapproved by the teacher) to gain the 'applause' of classmates who are significant to them.

'Withdrawal, Resistance and
Adaptation in Shaping the Experienced Curriculum' is the third theme in the book. The two chapters comprising this part give thoughtful insights in the strategies pupils may use to influence the curriculum. Angela Spaulding's study is situated in an upper-class primary school in London. The author provides a convincing account of how even sevenyear-olds deliberately use complex political strategies in order to avoid activities they do not appreciate. And maybe even more importantly, these young children are aware of the strategies they use and why they will or will not apply them. In the observed classroom, only girls use cooperating political strategies such as complementing and hugging their teacher, whereas the boys intentionally do not use these strategies. One of them explained that he was aware of the effectiveness of the girls' strategy, but he felt that this strategy was only reserved for them and for 'sissy boys' (p. 114). Boys are only real boys if they opt for more conflicting strategies. In addition to cooperative and conflicting strategies, these children are also aware of the power of the use of intermediaries to push their interests forward. 'So we told our parents... Now Mrs. Cole [the classroom teacher] can't do it [punishing the whole classroom] anymore' (p. 116). The main point Angela Spaulding is trying to make, is that the pupils do not simply want to subvert the teacher's agenda, but that they are acting as concerned learners, who are afraid of failure. However, the data presented in this chapter do not allow for this rather firm statement. Perhaps some pupils simply want to break through the monotony of daily classroom routine.

At the heart of John Nicholls' and Theresa Thorkildsen's chapter is a boy who named himself, after a project on Indians, 'Quiet Bird'. In Quiet Bird's life there is a sharp disconnection between his personal experiences outside the school and his school life. John Nicholls, Theresa Thorkildsen and the boy's teacher, Ann Bates, vividly depict their struggle to reach the boy and make sense of their data in terms of appropriate educational arrangements for him. From a curriculum perspective this is a very interesting chapter, because it not only provides insight in why 'Quiet Bird' is not doing well in school tasks, but it also describes the way the researcher and the teacher discuss and explore solutions for the boy's problem. In this chapter not only the pupil's voice is heard, but also the voices of the researcher and the teacher in their 'intellectual strug- 
gle' to make school life more meaningful and attractive for the boy.

Around the final theme of the book, 'Methodological Challenges', three chapters are grouped. In his chapter about observing children's playground activities Smith adheres to a pure phenomenological stance by warning researchers to be very cautious about judging their observations with broad categories in mind, such as genderrelated categories. He is afraid that these categories overshadow the uniqueness of the particular child in a particular situation. Unfortunately, Smith does not address how to aggregate those rich but highly contextualized, and therefore specific and anecdotal, findings to a more general level. In my opinion, Paul Connolly wrote a more intriguing chapter about the methodological challenges and pitfalls researchers face when studying children's perspectives. His main argument is that 'it is the researcher's own value base and assumptions about children and childhood that remain the most important factors in shaping the way that data on young children are collected, analyzed and written up' (p. 163). The author shows that both traditional testing techniques and innovative qualitative approaches may yield data that strongly reflect the researcher's beliefs about the cognitive and social (in)capabilities of young children. As several contributors argue in other chapters, Paul Connelly also shows that even young children can understand, apply and reflect upon a rich array of social strategies. But to uncover this, the researcher must give the children the space to demonstrate these capabilities. However, Paul Connolly is sensitive to the jeopardy of putting the researcher's words in the children's mouths, and also that the voices of the children in educational research are inevitably mediated by the researcher. But, his point of view does not lead to relativism about research findings, but to a reflexive approach in which researchers critically evaluate their own and each other's work. This chapter provides very rich examples of both kinds of evaluations.

The last chapter is written by Dennis Thiessen, one of the editors of the book. In this chapter he devotes himself to the difficult task of synthesizing the preceding ones. His discussion is focused on three levels: knowing about primary pupils' perspectives, acting on behalf of them, and working with these perspectives.

Rethinking the contributions of the different authors of the book, I believe that the editors did an excellent job in bringing the many-coloured voices of pupils to the attention of the reader and in convincing the reader of their importance in understanding curriculum issues. However, the advice on the pertinent curriculum question about how to work with these perspectives, both by teachers and educational policy makers, is rather vague and general. I would appreciate it if some authors in their further work will make the effort to link their research findings more closely to curriculum design, development and practice, as was so thoughtfully done by John Nicholls and Theresa Thorkildsen in their chapter about 'Quiet Bird'.

Ellen van den Berg

Curriculum as Conversation: Transforming Traditions of Teaching and Learning

Arthur N. Applebee (University of Chicago Press, Chicago, 1996), 150 pp., \$34.95 (hbk), ISBN 0-226- 
02121-1, \$12.95 (pbk), ISBN 0-226012123-8.

The debate about what knowledge should be included in American public school curricula is as old as the public schools themselves. In his book, Curriculum as Conversation, Arthur Applebee questions the current structure for curricula and offers an alternative that he believes will give meaning back to what is learned in school. He argues that 'the power of education is intimately bound up in the social and cultural traditions within which education is set'. Historically, tradition carries a negative connotation as it is criticized for being obsolete and lacking innovation. Applebee ascertains that tradition is not necessarily the enemy; that it is instead a question of 'knowledge-out-of-context' versus 'knowledge-in-action', which constitutes the way individuals use their past to fully participate in their future. $\mathrm{He}$ describes knowledge-in-action as tacit knowledge which is deeper and more ingrained and is only possessed when we have been immersed in the tradition underlying the idea. When students possess tacit knowledge, they not only have the presented facts, they also have an almost taken-for-granted understanding that they've pulled together or synthesized through the acquisition of other knowledge which, in many cases, comes from their individual human experience or schema. Knowledgeout-of-context, on the other hand, is knowledge that is on a surface level and isn't as useful in a practical format. This knowledge is seen when students simply memorize something that does not hold genuine meaning for them. Applebee advocates the need for schools to adopt a knowledge-in-action philosophy whereby students are actively engaged in integrating their past and future. When curricula are reformed to reflect knowledge-inaction a new theoretical framework emerges which equips students with the skills in interpret new situations and produce new solutions to problems.

As Applebee demonstrates in this book, students can learn to fully use the experiences of the past to shape the future through the process of conversation. In planning curricula, Applebee stresses the importance of instituting conversational domains. In schools these domains have been pre-established and take the form of disciplines such as language, mathematics, social studies, and science. A more appropriate emphasis might be domains that are culturally specific and imbue a natural facilitation for conversation centred around 'living traditions'. In order to accomplish this end, participation is key and students are actually 'doing' science or social studies instead of simply reading or being told about it.

Applebee discusses the way that individuals interact with tradition both in their everday life and in school. The notion of 'taking part' in tradition is emphasized in both arenas. The traditions that are established early in a child's life through family and community shape traditions that will be encountered later in school. In both cases Applebee describes how individuals interact with their environment through the use of cultural tools. This viewpoint parallels the school of thought held by constructivist theorists. Constructivism is gaining prominence in American education and is being touted in the teaching/learning literature for its progressive nature. This theoretical framework examines the social influence on how students build meaning. Constructivism rejects the notion that knowledge is acquired or obtained, rather it examines how learners actually construct knowledge 
for themselves through their interactions with others. One key element which constructivism and knowledgein-action share is the need for learners to construct knowledge through the use of cultural tools. One such tool is the spoken langugae that children acquire from an early age. These tools serve as instruments which help children make sense of the world.

Applebee relies on Grice's Cooperative Principle to characterize effective domains for conversation. These domains tend to share four characteristics: quality, quantity, relatedness and the manner in which the conversation is revealed. The quality of curricular conversation encompasses the ability of participants to contribute accurate information supported by appropriate evidence. Quality also entails the necessity of the material to serve as a catalyst for conversation that is meaningful. Appropriate quantity or breadth of material ensures that a sufficient amount of substantive material is covered tofoster and support conversation. A common complaint offered by educators is the difficulty they experience with covering current curricula. When the focus is on breadth instead of depth, students are denied the ability to work with complex understandings. In this situation, Applebee claims that 'dialogue' is transformed into 'monologue'. Students only acquire a surface acquaintance with knowledge when the goal of instruction is to cover large quantities of fragmented information. If curricula are not structured so that students can become active participants in discourse, their knowledge will only include knowledge-out-ofcontext that will only prove useful to the student on a temporary and limited basis. Relatedness pertains to what makes learning relevant to the individual. Instruction should not be delivered in isolated bits, rather in a context that is practical and useful in the real world. One buzzword that is being heard in educational arenas is integration. Sometimes integration is forced, however, and lessons are taught in the name of integration that have absolutely no relevance to the child. Learning that is relevant needs to connect to the student in some fashion, whether it be through one's own experiences or through realworld problems being faced in the child's community. The final component is the manner in which the domain is geared to foster curricular conversation. Again, Applebee takes on a constructivist point-of-view by asserting that "only through participation guided by others will students develop the knowledge-in-action that will enable them to participate effectively on their own'. Lev Vygotsky, a leader in constructivist theory, believed that each student possesses what he called 'a zone of proximal development'. This zone identifies the distance between that which a student can do alone and what the student is capable of doing when aided by a more advanced individual, whether it be a peer or a teacher. Vygotsky held that learning is not fully optimized unless students are assisted by a more advanced individual. The concept of the zone of proximal development is receiving increasing attention in educational circles.

Applebee also delineates various structures that may exist within a specific curriculum and how these structures affect the facilitation of sustained conversation. The most effective and comprehensive of those mentioned is the integrated curriculum where students make explicit the interrelationships of the curriculum. This concept spirals back to the notion of relatedness, one of the most important elements of curricula that fosters conversation. 
Applebee makes an irrefutable case for advocating curriculum as conversation in today's schools. It is unlikely that any educator would opt for knowledge-out-of-context when given the better choice, knowledge-in-action. While treating curricula as conversation may be a useful start to educational reform, great need still exists for radical reform. For example, given the premise that every student is educable, schools are structured such that every student is given the same amount of time to master the same curricula. In order to truly educate every student we need to break the age/grade barrier that we hold to so dearly. It is assumed that students of a same age are alike with respect to how they develop physically, emotionally, and academically. Few would debate the fact that students are different in these regards; however, schools do nothing to accommodate this natural process. Even though it is unfair to expect all students to be on the same timeline, we teach to the middle segment of the population while allowing the top to go unchallenged and the bottom to be passed through unprepared. Schools must first realize that students will require differing amounts of time to put knowledge into action. Once this goal and similar others are realized, schools can begin to focus on each learner's culture and experiential background.

Without the addition of these structural changes, schools will continue to breed knowledge-out-of-context. Applebee's book heightens the reader's awareness of the importance of perpetuating knowledge that takes the past into account while transforming the future. While not a cure-all for the ills of education, the recommendations put forth in this book do not appear to be a Band-Aid effect either, rather a step in the right direction toward positive curricular reform.
With thoughtful consideration of how our past experiences can facilitate conversation about the future, students can achieve gains that will help make learning more meaningful... and this certainly cannot be bad.

Barbara Day Tracie Yarbrough

Giving Kids the Business: The Commercialization of America's S chools

Alex Molnar (Westview Press, Boulder, Colorado, 1996), 240 pp., \$22.00 (hbk), ISBN 0-8133-2478-5.

A number of social, political, and economic forces have become interwoven in the last several years that have led to significantly greater involvement of the 'private sector' in the day-to-day life of teachers and students in US public schools. From the creation of career education programmes that begin as early as kindergarten to the establishment of for-profit high schools, a number of programmes have been created that serve the interests of the political 'new right' as they suggest ways to emphasize market-driven educational programmes. It is such programmes, especially as they relate to educational reform, school practice, and social policy, that Alex Molnar takes to task in Giving Kids the Business.

Beyond specific classroom offerings and educational proposals, the basic issue of what schools are - what their proper aims are, whose interests they ought to serve, what their mission should be, and the like - is increasingly being resolved by an appeal to replace a democratic discussion of public purposes by a narrow commitment to private gain. This is happening, Molnar argues, in part because of a 
political and ideological shift in the US and other industrialized nations since about the 1980s - celebrated, once again, as ushering in an era devoted to 'the end of ideology' by recentlyelected Prime Minister of the United Kingdom, T ony Blair. This movement is also being propelled by a correlative eff ort to cut back on 'the welfare state' as we privatize large segments of daily life and cut back on funding for, among other things, state schools.

These patterns of change have taken place, in the US, while the gap between the very wealthy and the very poor has been widening. That gap is often obscured by the almost daily celebration by the media of higher stock prices (and higher corporate profits), an apparently declining federal deficit, budget-cutting at the federal, state, and local levels, and so on. For the schools specifically, Molnar argues, this has meant a greater opening for the expansion of commercialization of school curricula and classroom practices, at the same time that the ideology of the new right seems to gain momentum. This opening is, at one level, understandable, given the lack of resources faced by many schools, especially those that serve children and students from the most marginalized circumstances. The result, as the author reports in Giving Kids the Business, is a sometimes 'commonsense' or unconscious embrace of materials that have at least implicit, and sometimes explicit, connections to a pro-business, conservative, ideological agenda.

Molnar provides a dazzling array of examples to support his view that US schools are now being inundated with free low-cost materials that serve to commercialize the curriculum and deflect the agendas of classroom teachers. $\mathrm{He}$ also adroitly points to several misconceptions that have been paraded by business leaders and by those arguing for expanded collaboration between schools and corporations. For example, like the publication of $A$ Nation at Risk, several groups, think tanks, and prominent individuals have blamed the schools for not keeping the US economy globally competitive. They have also suggested various educational reforms designed to increase the number of skilled workers, who might with the proper education help regain lost economic ground. Not only was a 'skills crisis' trumped up (or simply fabricated), but Molnar says that the language of human capital utilized by corporate America leaves much to be desired:

... a person searching through corporate reform literature would, in general, have little hope of finding concern about educational equity for girls or minority group members or about the simple justice of spending at least the same amount of money to educate each child. Nor do corporate-sponsored reforms consider the possibility that perhaps we should provide decent, humane schools for all our children because we love them and because childhood in the United States should be a rich and rewarding time during which children learn to care for each other through the example of adults who care for them. (pp. 4-5)

A narrow, essentially self-interested focus on education by corporate America has, Molnar tells us in example after example, misled teachers, parents and community members into thinking that the new right platform, and the materials that have been produced to further its aims, can provide an educational agenda that will serve children, and the rest of us, well. 
The basic direction which Molnar reports in this book is one that replaces an interest in civic life, the pursuit of the public interest and a re-emphasis on the common good, with a set of priorities connected to private gain, exclusivity, and economic power and political clout. Such forces might well remake the landscape not only of education, but of social life more generally. The infusion of private capital surreptitiously into the schools is only one example of this direction. Molnar has provided important insights into these social and ideological movements, and especially into the ways educational activities supported by the new right serve those movements. As he puts it:

The debate over public education reform cannot be understood by thinking only about schools. It is part of a much broader struggle: whether America will move in the direction of its democratic ideals or be further ensnared in the logic of the market. The outcome is by no means assured...

The challenge facing American society and its children is not how to find ever more ingenious ways to speed the market on its way. The real challenge of the next century is to take control of our lives back from the market. (p. 184)

Reasserting the need for democratic practices, public values, the common good, and civic virtue and action, is obviously no easy or simple matter at any time, and especially now, given the economic and ideological capital currently held by the market forces and their new right allies who enjoy significant political and cultural influence. Molnar has provided educators with important descriptions and analyses that can help the reader understand better, and more fully, what we are up against.
The analysis provided by the author - and it is one that all educators and citizens need to take seriously - is both timely and important. Yet we must go beyond that analysis. Moving beyond critique, we can develop commitments and strategies encompassing actions that can resist the forces that Molnar identifies. Indeed, there are many teachers currently working in state schools who not only recognize the dangers he chronicles, but who are taking action to develop alternatives that are both courageous and committed to social justice. Teachers at all levels need to both celebrate and join those struggles. Educators, acting together in the pursuit of democratic, socially just practices, can continue to find ways to work with researchers, community members, students, and others to resist the market-driven reforms and treatises that, as Molnar documents, sometimes lead to misshapen and politically motivated reforms that harm students. That will require forms of collaborative action, as well as forms of analysis, that can lead to changes in day-to-day life in schools and elsewhere. Taking a stand on the forms of inequality and oppression that Molnar documents, we may come to see, and act on, the need to create moral actions aimed at taking back educational institutions, so that US public school teachers and their pupils, college professors and their students, and the public in general can reframe educational agendas in ways that indeed lead us to take back 'control of our lives'. This is, finally, the hope of democratic education.

Landon E. Beyer 
Developments and Directions in Geographical Education

Edited by Rod GERBER and JoHN LiDstone (Taylor \& Francis, Ltd., Philadelphia, PA, 1996), 236 pp., \$59.00, IS BN 1-873150-20-2.

Within the past two decades, the subject of geography has received renewed attention from educators and policy makers concerned with students' presumed lack of geographical knowledge and skill. Despite the attention, however, the editors of Developments and Directions in Geographical Education report that 'a considerable number of geographical educators at international conferences indicate that the place of geographical education in the school curriculum is under threat or is in fact diminishing' (p. 1). One of the editors' chief aims is to identify directions that will secure the future of geography in the school curriculum. Among such directions are: reorientation in school curricula; increased emphasis on research in geographical education; reconsideration of spatial understanding and its development; consideration of the role of geography in promoting ethics and values; technology and innovation; and professionalism in geographical education.

Rod Gerber and John Lidstone have assembled fourteen essays on current international theory and practice in geography education. Although the majority of the contributors are from Australia, a handful also hail from the UK, Hong Kong, Germany and the US. The diversity of the contributors provides the reader with an intriguing range of perspectives on issues in geography education.

This book should appeal to a fairly wide audience of educators. Teachers will read with interest a number of essays specifically devoted to classroom practice and issues of professionalism and ethics. Curriculum developers will enjoy descriptions of various curricular and assessment methods that are currently being implemented in a variety of countries. Policy makers and others will find useful the overview of rationales for promoting geography, recommendations for professional development, and discussion of issues surrounding the teaching of ethics and values through geography. The researcher familiar with quantitative approaches to research in geography education will welcome Rod Gerber's general discussion of the role of and need for qualitative research in this subject.

Gerber and Lidstone have organized the text into two sections: 'Curriculum Development in Geographical Education' and 'Directions in Geographical Education'. Although there is some overlap in content, the first section generally addresses issues of curriculum, instruction and assessment, and the second focuses on directions for research, professionalism, ethics, national assessment, and learning.

One of the themes that runs through several of the chapters in the first section is the need to expand the subject of geography from a somewhat minimalist treatment of location to a subject capable of unifying many areas of the curriculum. In the opening essay, 'Theories and practices in the development of curriculums in geography', Don Biddle traces the history of the subject in teacher education programmes from a descriptive regional approach to a more scientific researchoriented approach for investigating environmental problems, or to a systems approach. He concludes by noting that curricular emphasis in many Englishspeaking countries is being placed on a 
more humanistic approach to the subject which highlights issue-based topics such as environmental pollution, sustainable resource development, changing work and leisure patterns, and so on.

Less optimistic are the essays by Geoff Conolly and Michael Naish. In 'Setting the curriculum: a place for geography', Conolly points out that the question of how best to teach geography is far from settled, either in theory or practice. He traces the status of the subject in a variety of countries and notes the following obstacles to its effective implementation in Australia: the teaching of geography by nonspecialists, the status of the subject as an elective, and teachers' limited knowledge of the subject. For those who look to federal mandates as a needed solution to geography's fragile status in the curriculum, Michael Naish of the UK sounds a cautionary note. In his essay, 'The geography curriculum: a martyr to epistemology?' he argues that prior to the establishment of a prescribed role for geography in the National Curriculum, creative curriculum development in geography had flourished, only to be replaced by 'an outdated model of geography, a lack of commitment to enquiry learning....ignoring the more humanistic side and focusing on the factual' (p. 74).

A number of essays seek to advance the status of geography education by recommending new approaches to curriculum, instruction, and assessment. Drawing on D. A. Schön's concept of the reflective practitioner, Lindsay Parry encourages teacher educators to promote reflective decision-making and curriculum inquiry in geography among beginning and experienced teachers. Essays by Colin Davey and John Fien discuss geography's role in promoting environmental education. For Davey, 'good geographical educa- tion is also environmental education'. $\mathrm{He}$ argues for the use of key concepts and questions in organizing the geography curriculum to address the natural environment, the social environment, the built environment, and the spatial environment. Fien presents geography as a vehicle for teaching environmental values and ethics and for helping students to grapple with the social and environmental problems that flow from poverty, hunger and exploitation. Concluding this section is Philip Stimpson's essay on assessment. Understanding that assessment is often the tail that wags the dog in educational policy and practice, Stimpson argues for the use of authentic assessment methods in geography education, identifying the following features of a reconceptualized assessment system: relevance, process, values, divergent thinking, breadth, holistic approaches, group as well as individual tasks, and flexible pupil responses.

The second section encompasses a more eclectic range of topics: directions in research, issues of professionalism, ethics and controversial issues, national assessment, and learning. In 'Directions for research in geographical education', Rod Gerber emphasizes the need for qualitative research to shed light on the current status of geography education and a better understanding of how young people learn geography. He concludes by recommending that geographical educators undertake research on their own practice in order to raise their field to a higher level. Gerber's conclusion ties in nicely with the susequent essay by John Lidstone, entitled 'Professionalism in geographical education'. Lidstone identifies a number of challenges to the geography teacher including changes in geography as an academic discipline requiring teachers to virtually reconstruct themselves as modern geographers, the need 
to reflect on and distinguish between information and indoctrination in the politically based (and thus partisan) environmental movement, and the rapid pace of structural and cultural changes teachers face today. In 'New meanings in time and space: ethical dilemmas for teachers', Margaret Robinson discusses the implications of an additional challenge to geography teachers: the advent of on-line information through the Internet.

The reader of the essays collected in this volume will be struck by the increasingly complex role of the geography teacher. He or she must simultaneously keep up with advances in the field, inculcate environmental ethics and values while avoiding the semblance of indoctrination, experiment with new approaches to curricular development, instruction, and assessment, and serve as an advocate for a field that still struggles to find its place in the school curriculum.

Will geography become implemented as a core subject in schoolrooms across the world? Geography currently competes with two other school subjects that comprise many of the same concepts and objectives: environmental studies and social studies. Although a number of authors noted this, it is not the subject of any of the essays collected here. This is an unfortunate omission in an otherwise highly useful text. A significant proportion of the authors' references are drawn from journals devoted to environmental education or social studies. Many of the contributors claim that geography has the potential to unify many areas of the curriculum. In fact, this claim serves as a common rationale for the role of geography as a core school subject. But how realistic is it to expect geography to play such a key role when today it has become commonly institutionalized as a subset of other subjects? 'I do teach geography', insisted one teacher with whom I spoke this week. 'It's included in several chapters of our social studies text.' How many other educators might answer in similar fashion?

While the debate over geography's role in the curriculum might have received more attention, the editors of this volume have provided geography educators with a valuable resource in bringing together the essays comprising this text. It is a good beginning, and it will be interesting to see, ten years' hence, what headway has been made in geography education in the countries represented here.

\section{Kim Tolley}

Modern Times? Work, Professionalism and Citizenship in Teaching

Martin Lawn (Falmer Press, London, 1996), 176 pp., \$72.95 (hbk), ISBN 07507-0495-0, \$24.95 (pbk), ISBN 07507-0496-9.

This is not a book about teaching in the way that Willard Waller's The Sociology of Teaching, or Dan Lortie's School Teacher are books about teaching. For one thing, although the word 'work' appears in the title, the reader learns nothing about what teachers, as workers, actually do. Nor is the author particularly concerned with definitions of, or arguments about the nature of professionalism, or the nature of citizenship. Lawn's project here is to gather together the substantial corpus of writing which he has produced over the last ten years or so around themes of the relationship of schooling to the state, especially as it stimulates and affects the political attitudes and actions of teachers and teacher unions. 
Or, to use his own words: 'I am interested in the way teachers act politically within education, acting within their teacher associations and making alliances with other groups or using a language of politics drawn from outside teaching to explore their roles, relations and work' (pp. 9-10). The arena within which these teachers are acting is the education system of England and Wales, and the period within which they are acting is, roughly, 1900-1990.

The perspective employed in these essays is, at one and the same time, abstract and concrete: abstract in the sense that words like 'work' and 'professionalism' are used, not to refer to specific, task-oriented activities or codes of conduct, but as evocative terms within a saga of struggle between 'progressive actors' (a category which, one assumes, will include most, if not all teachers) and 'policy makers' who impose their will either through bureaucratic control or through propagation of the 'myth of professional engagement'. Concreteness is provided by quite detailed accounts of specific events, such as the development of new policies towards teachers by Lord Eustace Percy as President of the Board of Education in the 1920s or the organization of strikes by the major English teacher unions over the 1985 pay settlement.

Most of these events are presented as illustrations of the general proposition that those with power are invariably dishonest actors. Percy's intention that teachers should be 'given a sense of reasonable independence' is interpreted as 'a sophisticated attempt to manage teachers' - an initiative rendered the more reprehensible because it could be linked to Lugard's model of 'indirect rule' for the colonies. And even Labour party theorists such as G. D. H. Cole seem to have been on dangerously similar ground in advocating that 'control of each industry...must be placed, as a trust on behalf of the community, in the hands of the workers engaged in it'.

Lawn's chronicling of the shift, beginning in the 1920 s, from regulatory control to the co-option of teachers into a 'partnership' between central government, local government and teaching unions is insightful and helpful in unravelling the politics of more recent backtracking, such as the imposition of a national curriculum. Its interest is enhanced by the fact that, though his story is mainly one of a kind of deterministic evolution of the social order, he himself adopts a moral stance - or rather, it seems, a number of moral stances. He clearly dislikes Lord Percy and all his works and, in that context, declares a preference for overt centralization over partnership 'because it is not hypocritical'. Yet soon afterwards we find him supporting, in the pages of Marxism Today, teachers who, in 1985, were striking against the centralist ambitions of Sir Keith Joseph who was 'reasserting the traditional role of the State in the educational system and reverting to the direct management that was common at the turn of the century'.

The crucial difference it seems is that 'indirect rule' defuses the revolutionary tendencies of the teaching force. Keith Joseph may have been less 'hypocritical' than Eustace Percy, but, by that very fact, he invites the confrontation that 'progressives' need if they are to be roused to acts of subversion. It is the Burston School strike of 1913 which offers the model for how progressive teachers should earn their laurels as moral actors in contrast to devious or power-hungry politicians and bureaucrats. The 'struggle by the Burston community and its teachers' is described as 'an 
inspirational example of politics in school'. This it may well have been, but the interesting question is why they, and other like-minded activists, should be uniquely deserving of the label of morally upright actors among so many involved in various ways in the politics of teaching. Indeed the emphasis on teaching as a fundamentally political activity (or should I say 'act'?) seems here to be overdone. If every act is a political act, then politics ceases to have any meaning. And if, therefore, judgements can be made about what in the life of teachers is political and what is not, I would claim that, most of the time, and in most places, teachers are not political animals, and that the assertion that they are involves a serious distortion of the facts.

My own experience as an officer of the National Union of Teachers and local association president in the 1960 s taught me that the vast majority of teachers had little interest in politics of any sort. Politics was not something endemic to teaching, or even to activities of the Union. Politics came to the fore only in relation to specific issues, and even then could usually be kept apart from other demands upon the union such as looking after the individual concerns of members, encouraging curriculum development and dealing with the press and the public.

Perhaps, as Lawn suggests, we were seduced by the myth of partnership. Certainly it was the first violation of the partnership principle by Edward Boyle as Minister of Education in 1963 that was to galvanize my association, along with almost every other one, into unaccustomed political action. Boyle had the temerity to make a unilateral adjustment to a pay settlement. It was a small adjustment, and many, even in the union, thought it a sensible one. But the way in which it was made struck at the heart of the notion of partnership. At the annual conference, the normally pacific rank and file were outraged by the lack of militancy over the affair shown by union-supported Labour Members of Parliament (to which George Thomas, later Speaker of the House, notably replied 'Me not militant? I come from T onypandy!').

Partnership, of course, was not confined to the education service. It was a very convenient way of managing the business of government across a wide range of activities - agriculture, health, housing and so on. The idea was to create a 'sub-government' by letting those on the inside of the business get together to decide what should be done and how. Then this would be rubberstamped (or sometimes ignored) by Parliament. One insider interest was always the relevant government department (usually represented by civil servants rather than ministers). Others were professionals or trade unions of various kinds, employers and manufacturers associations and local authorities. It could be a very efficient way of proceeding. People in the same business who knew each other could get things done expeditiously without being tripped up by political entanglements. And, on the other side, ministers could have an easy ride. But these advantages turned out, in the long run, to be serious disadvantages. Insiders can have a lamentably biased view of what their businesses should be doing, and exemption from direct political surveillance leaves them with little incentive to act in the public interest. Hardly anyone these days can be found who would argue that we should go back to the time when road builders, in concert with the Ministry of Transport, could privately decide how much of the country should be covered in tarmac. Only the Ministry of Agriculture remains as a last bastion 
of sub-government, but, as the mad cow disease crisis gets more and more expensive, even that looks set to fall.

So what of teachers? Looking back, I think I could happily see Edward Boyle as a prisoner of history. 'Secondary education for all' probably signalled the end of 'partnership'. With almost everyone having a serious stake in the education service, and with costs mounting astronomically, how was it possible for decision-making to be left to insider? The writing was on the wall long before Jim Callaghan made his famous Ruskin College speech in 1976.

The real problem with partnership was not that it was 'hypocritical', but that it was far too comfortable. The era initiated by Lord Eustace Percy was one in which teachers and local authorities could go to sleep. In so far as they were activists, teachers were activists on their own territory - the classroom. And when they had to become accountable to a wider public, neither they nor their leaders were in any shape to respond to the challenge. Hence the takeover of teaching by assorted exponents of management-speak (or, as Lawn would have it, the rise of 'PostFordism').

It is a fascinating, if depressing story. If it interests you, read this book.

\section{William A. Reid}

\section{Just Girls: Hidden Literacies and Life in Junior High}

Margaret J. Finders (Teachers College Press, New York, 1997), 160 pp., \$38.00 (hbk), ISBN 0-80773561-2, \$17.95 (pbk), ISBN 0-8077$3560-4$.

Just Girls: Hidden Literacies and Life in Junior High by Margaret J. Finders is a book about the daily lives of young adolescent girls. It is an ethnographic study of the literate practices among seventh grade girls in a mid-western junior high school. Finders documents the literacy activities of five girls both in school and, to some extent, in their homes. The five girls studied fall into two groups - the 'queens' and the 'cookies'. The queens are a group of three students for whom friendship and peer activities mean everything. School is but one arena of their social life, a place for being with friends and for establishing as well as confirming their popularity. The cookies, on the other hand, are two individual girls who have virtually no peer-centred social life and whose focus in school centres on academic work and success. Hence this book examines the literate practices of girls living sharply contrasting lives the popular and academically uninterested girls as well as the unpopular but academically oriented girls.

The literate practices that are examined include both the school-sanctioned literacies, such as language arts activities and yearbook signing, and the hidden literacies, such as note writing, and reading teen magazines. The literate practices of these girls bear little relationship to notions such as cultural or critical literacy, but literacy events have great social significance for the girls, and the practices are nonetheless very different for the two groups. A girl's label is clearly related to the kinds of activity she can engage in. For example, the queens hardly participate in the school-sanctioned literate activities other than the yearbook signing, which they in fact seem to dominate. The yearbook signing, sanctioned by the teachers who devote classtime to it, is a scene for the queens to confirm their popularity. On the other hand, the queens cannot participate in ordinary language arts activities because they are 
for those interested in school academically and would therefore not fit the queens' image. Language arts activities are relegated to the unpopular girls, such as the cookies. The queens concentrate instead on note-writing, bathroom graffiti-writing, and reading teen magazines. The cookies engage mostly in school-sanctioned activities. In fact, in school they do not seem to engage in any other activity at all. At home they read novels and magazines as well.

The title of the book indicates a focus on the hidden literacies, but at least as striking is how the girls deal with various school-sanctioned literate activities. Seeing how the girls engage in or disengage from these reveals a good deal about the meaning of popularity. To be popular means a world full of rules of behaviour and conduct. The rules determine who the queens can interact with and how. Finders devotes a chapter to the yearbook-signing in order to show how this signing exemplifies the existing hierarchy in school. The queens receive many requests for signing books. However, they ignore the requests of the most unpopular in order not to dilute the importance of their signature. The cookies, on the other hand, do not sign the yearbook or even buy it. The teachers act as though everybody buys the yearbook and allow classtime for the signing. As it turns out about a third of the students do not buy the yearbook. One reason the cookies do not buy it is because they do not find themselves in it. It is not about them and their school year focused on academic pursuits. Unlike the queens, they do not participate in extracurricular activities and, hence, there are not pictures of them. This is indicative of the fragile connection to school that the cookies have.

In junior high the cookies seem to have lost almost all their social connections in school. The two cookies, who consider themselves friends, manage to meet only briefly for lunch every second day in school. Their connections to teachers are weak as well. They do the required work well but teachers seem not to pay them much attention. One teacher's comment that 'she is just a mouse' seems to exemplify their attitude towards these girls. The cookies do not interact with peers outside school either. They both live in trailer parks and one of the families does not have a car. The lack of money and a car limits the girls' involvement with others as well as in extracurricular activities. Since their parents will not be able to pay for college, the cookies know that they have to do very well in school in order to get scholarships if they want to go on. The cookies have to be more tuned in to their future opportunities than the queens in view of their lower social class status.

The queens seem to find ample opportunities to socialize with each other in junior high. It is not clear why it is possible for the queens but not the cookies to nurture their friendships on school time. The queens have parents who, while they might worry about their daughters' high level of social involvement, basically think it is healthy and important for their development. The parents drive them to activities and to leisure pursuits such as visits to the mall. While the queens are focused on peer relations they are not cut off from their parents, and one of the mothers especially seems to be a trusted friend of all the girls. Success in school is linked to maintaining good relations at home; the girls know that they have to do fairly well in school because otherwise they lose their privileges at home. These girls are not potential dropouts. In school they do only the required minimum amount of work, they might buy a paper from one of the girls who likes writing, and they 
certainly do not hesitate to kiss up to the teachers in order to get a good grade. The queens have a social network to fall back on if things do not work out that the cookies do not have. As Finders shows, the social class advantages are evident as well in how teachers treat them.

This work presents findings about teacher views and behaviour that are illuminating both for practising as well as pre-service teachers. It is quite clear that both groups of girls are stereotyped by the teachers who know very little about the girls' lives outside school, even if these teachers seem to be caring individuals who take their work seriously. The teachers seem to have a better understanding of the inand out-of-school life of the queens. It is a basic middle-class life that the teachers are familiar with. However, they seem to think of the queens pretty much as airheads. For example, the language arts teacher does not believe that the queens do any outside reading when in fact they all read and one of them is an avid reader even of nonfiction books. More important is the lack of understanding teachers have of the life of the cookies. They do not seem to know anything about their living conditions other than that they live in a trailer park, and the parents' values and priorities are a mystery to them. Actually it is the mothers that are important. They are the ones that hold the family tightly together. The mothers worry (and rightly so) that the teachers do not know their girls and they see the school's role as much more limited than do the parents of the queens. They do not want their girls involved in extracurricular activities. They want the school to give their daughters a good academic education and leave the rest to them. They do not want their daughters focusing on peers or hanging out with friends on week- ends. Free time is generally spent with the family. Many pre-service teachers worry about parent involvement for poorer students, but they often have a very narrow definition of parent involvement. I suspect that few preservice teachers would have an understanding of the values and priorities of the mothers of the cookies or of the cookies themselves.

On the whole, Finders' account of the queens is more thorough than that of the cookies. For example, she makes the case that the queens resist schoolsanctioned literacy through note-writing, graffiti-writing and pretending not to read the assigned literature. This may well be so. However, the oppositional behaviour of the cookies is not presented as resistance. For example, the cookies like to work on their own. They consider group work cheating. They do not like to ask for help from other students. Hence, when asked to write a response to another student's writing one of the cookies writes a response to her own writing by using a different handwriting. How is this oppositional behaviour different from the queens pretending not to do the assigned reading? A more detailed description of the cookies' lives in school would also have been helpful in understanding, for example, how the teacher did not notice that this girl never worked with another student on writing feedback. The cookies held very firm views on what was right and wrong with regard to their writing. They did not want feedback written on their papers by the teachers. They focused on the neatness of the work and did the assignments as they thought the teachers preferred them, not based on what they thought to be interesting topics and not pursuing teacher suggestions to do different kinds of things. $\mathrm{T}$ his gives us a hint of how restricted their lives were and how their actions 
made their experiences and opportunities even more restricted.

Finders argues that the cookies have chosen this self-isolation; that this is what they want. This judgement is difficult to support, however, based on the existing description of the cookies' experiences. Is it not possible that the cookies' experiences in school have more or less forced them to isolate themselves in order to survive in school? And they do need to survive and do well academically since they are poor and school is their chance to have future opportunities. One wonders also what their interactions with other students are like? Are they teased, harassed or ignored because they are poor and live in a trailer park? What does it mean to be unpopular? How do girls interact with them? How do the boys treat them? Overall the boys tend to be almost absent from the girls' lives which is somewhat surprising considering the age of the girls. Some of the questions about what it means to be popular or unpopular might have been further illuminated by including a couple of girls nearer the social centre, girls neither extremely isolated and unpopular nor very popular social butterflies.

Finders' work includes a critique of student-centred pedagogy as being built on a series of myths about literacy and adolescence. She advocates instead a socio-cultural perspective and a student-negotiated pedagogy. As an example of what would be different in the classroom she suggests portfolios as a way 'to broaden students' notions of literacy' and 'to make visible the political tensions that accompany literate choices' (p. 126). She sees critical reflection as missing in student-centred pedagogy. Even though Finders does not elaborate on her suggestions for changes it is possible to imagine how this approach could be empowering for the girls. However, it is not clear how such an approach would deal with the cookies' mothers whose views seem to clash with such an approach. These mothers do not desire their girls to have a 'more critical awareness' or an increased ability to revise their roles. Finally, it would have been interesting to know how Finders sees this studentnegotiated pedagogy addressing the fundamental social class issues underlying much of what this book on girls' literacy development reveals.

Gunilla Holm

\section{Reviewers}

Landon E. Beyer is associate dean for teacher education at Indiana University, Bloomington. His interests include curriculum theory and development, the social foundations of education, and alternative forms of teacher education.

Barbara Day is Chair, Curriculum and Instruction, and Director of the Teaching Fellows Program at the University of North Carolina at Chapel Hill. She has been president of the Association for Supervision and Curriculum Development.

Gunilla Holm is an associate professor in the Department of Education and Professional Development at Western Michigan University. Her research interests centre on gender, social class and ethnicity issues in education

William A. Reid is a visiting professor of curriculum and instruction at the University of Texas at Austin. $\mathrm{He}$ was president of the City of Cambridge Teachers Association (National Union of Teachers) in 1967-68.

Kim Tolley is an assistant professor of education at the College of Notre Dame, California. Her research interests include curriculum history and history of education. 
Ellen van den Berg is on the Faculty of Educational Science and Technology at the University of Twente, The Netherlands. Her interests include the place of technology in teacher education.
Tracie Yarbrough is a doctoral student in curriculum and instruction at the University of North Carolina at Chapel Hill. 